\title{
Procedural Aspects of the International Legal Regime for Climate Change: Early Operation of the Kyoto Protocol's Compliance System
}

\section{Osamu Yoshida*}

This paper examines the early operation of the Kyoto Protocol's non-compliance procedure since 2006. Several important non-compliance cases recently or currently before the Kyoto Compliance Committee of the procedures and mechanisms deserve to be analysed and discussed. As we may see, the enforcement branch of the Compliance Committee has dealt with some important cases of non-compliance; Among them, from the viewpoint of interpretation or application of international environmental treaties, the question of compliance by Croatia would be particularly interesting. What must be noticed is that the Kyoto Protocol's NCP has prepared a multilateral forum which enables both the parties and the enforcement branch to base their arguments on international legal perspectives. This examination will also contribute to contested theories of compliance with international legal rules.

\section{Keywords}

Kyoto Protocol, Non-compliance Procedures, Compliance Mechanisms, Global Climate Change

\footnotetext{
Associate Professor of Public International Law and Organizations at the University of Tsukuba. Dr.Phil. (Edinburgh). Visiting Fellow, Institute of International Law and International Relations, Vienna University (2003-4). At present he serves as a Member of the I.L.A. Committee on the Legal Principles relating to Climate Change. The author may be contacted at: yoshida@social.tsukuba.ac.jp/Address: Graduate School of Humanities and Social Sciences, University of Tsukuba, 1-1-1 Tennodai, Tsukuba 305-8573, Japan.
} 


\section{Introduction}

One of the conspicuous characteristics of international environmental law is the development of so-called 'non-compliance procedures' ("NCPs"). It is contained in the procedural aspect of many recent 'sectoral' environmental regimes. ${ }^{1}$ In this respect, noticeable at the outset is the adoption of the non-compliance procedure in 1990 under the Montreal Protocol on the Substances that Deplete the Ozone Layer of 1987.2 Noncompliance with or non-performance of the ozone treaty obligations affects the international community as a whole rather than being geographically limited to particular sovereign states or even individuals under states' jurisdiction. Thus, 'ozone disputes' are totally different from environmental disputes concerning transboundary air pollution or the conservation of living or non-living natural resources. It can easily be assumed that traditional methods of procedures for dispute settlement, such as those envisaged in Article 33 of the United Nations Charter would not necessarily be preferred approaches in this context. ${ }^{3}$ As Günther Handl notes, what is required here is "regime-specific legal compliance mechanisms" of a more innovative nature. 4

The Montreal-type NCP may be triggered by one party against another, a party itself which is in non-compliance, and the Ozone Secretariat of the United Nations Environment Programme ("UNEP"). The newly established Implementation Committee as the "legitimate first stop" 5 in any formal discussion has examined and decided most non-compliance issues. Yet, the role and capability of the Committee is

1 See generally Patricia Birnie, Alan Boyle \& Catherine Redgwell, International LaW and the Environment 245-50 (3d ed. 2009); Philippe Sands, Principles of International Environmental LaW 205-10 (2d. ed. 2003); Gerhard Loibl, International Environmental Agreements - “Compliance Mechanisms and Procedures at the Crossroads?," in The Law of International Relations: Liber Amicorum Hanspeter Neuhold 191 (August Reinisch \& Ursula Kriebaum eds., 2007); M. A. Fitzmaurice \& C. Redgwell, Environmental Non-Compliance Procedures and International Law, 31 Neth. Y.B. INT' L L. 35 (2000); Jan Klabbers, Compliance Procedures, in The OxfoRD Handbook of International Environmental LaW 995 (Daniel Bodansky et al. eds., 2007); Malgosia Fitzmaurice, Environmental Compliance Control, in ENCYClopedia of PUB. InT'L L. (Rüdiger Wolfrum ed., 2010), available at http://www.mpepil.com (last visited on Mar. 4, 2011).

2 On the NCP of the Montreal Protocol, see generally Osamu Yoshida, Soft Enforcement of Treaties: The Montreal Protocol's Noncompliance Procedure and the Functions of Internal International Institutions, 10 CoLo. J. INT' L Envtl. L. \& Pol'y 95 (1999); Gilbert M. Bankobeza, Ozone Protection: The International Regime ch. V (2005). The text of the Protocol is reprinted in 26 I.L.M. 1550 (1987).

3 Osamu Yoshida, The International Legal Régime for the Protection of the Stratospheric Ozone Layer: International LaW, International RÉGimes and Sustainable Development 173-6 (2001).

4 Günther Handl, Controlling Implementation of and Compliance with International Environmental Commitments, 5 Colo. J. INT' L ENVTL. L. \& POL' Y 305, 327 (1999).

5 David G. Victor, The Early Operation and Effectiveness of the Montreal Protocol's non-Compliance Procedure 36 (1996). 
strictly limited to recommendations; it is not granted comprehensive, but only conciliatory, powers. 6 Therefore, more vexing questions may have to be referred to the supreme organ of the treaty regime, the Meeting of the Parties ("MOP") of the Protocol, or be reviewed by other appropriate settlement procedures.

At present, such NCPs are incorporated in many multilateral environmental agreements ("MEAs"). Some examples of these MEAs include the following: NCP under the Protocol to the 1979 Convention on Long-Range Transboundary Air Pollution on Further Reduction of Sulphur Emissions (1994 Oslo Sulphur Protocol7); 8 the Mechanism for Promoting Implementation and Compliance with the Basel Convention on the Control of Transboundary Movements of Hazardous Wastes and Their Disposal (1989 Basel Convention'9);10 the Compliance Procedures and Mechanisms of the Protocol to the 1972 Convention on the Prevention of Marine Pollution by Dumping of Wastes and Other Matter (1996 Protocol11);12 the Procedures and Mechanisms on Compliance under the 2000 Cartagena Protocol on Biosafety to the 1992 Convention on Biological Diversity (2000 Cartagena Protocol13);14 and the Procedures and Mechanisms established under the Kyoto Protocol to the 1992 United Nations Framework Convention on Climate Change ("UNFCCC")15 (1997 Kyoto Protocol16). The Montreal Protocol's NCP has often been criticized as too 'soft' in its nature; "the framers of the Montreal Protocol erroneously assumed that all parties are rational actors." 17 The NCP recently established under the Kyoto Protocol seems to be based on lessons learned

33 I.L.M. 1542 (1994).

8 Doc. EB.AIR/WG.5/CPR.13; Yoshida, supra note 3, at 175.

928 I.L.M. 657 (1994).

10 Akiho Shibata, Ensuring Compliance with the Basel Convention - Its Unique Features, in EnsuRING ComPLIANCE WITH Multilateral Environmental Agreements: A Dialogue Between Practitioners and Academia 69 (Ulrich Beyerlin et al. eds., 2006).

1136 I.L.M. 7 (1997).

12 See Seline Trevisanut, The Compliance Procedures and Mechanisms of the 1996 Protocol to the 1972 London Convention on the Prevention of Marine Pollution by Dumping of Wastes and other Matter, in Non-COMPLIANCE Procedures and Mechanisms and the EFFectiveness of International Environmental Agreements 49 (Tullio Treves et al. eds., 2009).

13 I.L.M. 1027 (2000).

14 Chiara Ragni, Procedures and Mechanisms on Compliance under the 2000 Cartagem Protocol on Biosafety to the 1992 Convention on Biological Diversity, in Treves et al., supra note 12, at 101.

1531 I.L.M. 851 (1992).

1637 I.L.M. 22 (1998). On the climate change regime, see generally FARHANA YAMIN \& JOANNA DEPLEDGE, THE International Climate Change Regime: A Guide to Rules, Institutions and Procedures (2004).

17 Nina E. Bafundo, Compliance with the Ozone Treaty: Weak States and the Principle of Common but Differentiated Responsibility, Am. U. Int' L L. Rev. 461, at 480-1 (2006). See also Alexander Gillespie, Climate Change, Ozone Depletion and Air Pollution: Legal Commentaries With the ConteXt of SCIENCE AND Policy 221 (2006) (noting that in most cases, non-compliance has been dealt with in a strict and uniform manner). 
from the Montreal Protocol model, 18 whose enforcement branch is empowered to take more stringent measures of a 'punitive' character. ${ }^{19}$ However, whether the Kyoto Protocol's NCP is more successful than the Montreal-based NCP must be assessed against the background of its 'actual practice' among the contracting parties, rather than from the written contents of the legal instruments relating to compliance.

Keeping this in mind, this paper examines the early operation of the Kyoto Protocol's NCP since 2006. Although non-compliance with 2012 emissions targets is not an issue, as we shall see in Section III below, several important non-compliance cases recently or currently before the Compliance Committee deserve to be analysed and discussed. This examination will also contribute to contested theories of compliance with international legal rules. 20 As a beginning, we will briefly observe the Kyoto Protocol's compliance procedures and mechanisms.

\section{The Kyoto Protocol and Its Compliance Mechanism}

Article 18 of the Kyoto Protocol provides that, at its first session, the Conference of the Parties serving as the meeting of the Parties to this Protocol ("CMP") shall approve "appropriate and effective procedures and mechanisms" to determine and address cases of non-compliance with the provisions of the Protocol.21 Such procedures and mechanisms can be found in the annex to decision 27/CMP.122 and in the Rules of Procedure of the Compliance Committee (annex to decision 4/CMP.223). Decision

18 On this point, see e.g., Jacob Werksman, Compliance and the Kyoto Protocol: Building a Backbone into a 'Flexible' Regime, 9 Y.B. Int' L EnVtl. L. 48, at 70-4 (1999); Sebastian Oberthür \& Hermann E. отt, The Kyoto Protocol: International Climate Policy for the 21st Century 219-22 (1999); Gilbert M. Bankobeza, The Ozone Protection Non-Compliance Mechanism: A Model for Implementation of Climate Change Convention and the Kyoto Protocol, in Dynamics of International LaW In the Millennium 346 (R. K. Dixit \& C. Jayaraj eds., 2004).

19 See Sections II below.

20 For a discussion, see e.g., Markus Burgtaller, Theories of Compliance With INTERNATional LaW (2005).

21 On the negotiating history of this article see e.g., Oberthür \& Ott, supra note 18, at 216-8; Maas M. Goote, Noncompliance procedures, 11 Y.B. INT' L ENVTL. L. 124-31 (2001).

22 UNFCCC, Conference of the Parties Serving as the Meeting of the Parties to the Kyoto Protocol, Montreal, Can., Nov. 28-Dec. 10, 2005, Decisions Adopted by the Conference of the Parties Serving as the Meeting of the Parties to the Kyoto Protocol, at 92, Doc. FCCC/KP/CMP/2005/8/Add.3 (Mar. 30, 2006), available at http://afoludata.jrc.ec.europa.eu/ events/Kyoto_technical_workshop/08a03.pdf (last visited on Mar. 4, 2011).

23 UNFCCC, Conference of the Parties Serving as the Meeting of the Parties to the Kyoto Protocol, Nairobi, Kenya, Nov. 6-17, 2006, Decisions Adopted by the Conference of the Parties Serving as the Meeting of the Parties to the Kyoto Protocol, at 17, Doc. FCCC/KP/CMP/2006/10/Add.1 (Mar. 2, 2007), available at http://unfccc.int/resource/ docs/2006/cmp2/eng/10a01.pdf (last visited on Mar. 4, 2011). 
27/CMP.1 is an affirmation of decision 24/CP.7,24 adopted previously by the Conference of the Parties to the Convention ("COP") in Marrakech in 2001.

The objective of the procedures and mechanisms is "to facilitate, promote and enforce compliance with the commitments under the Protocol." 25 The inclusion of the term 'enforce' would be important because this may be regarded as a statement that the Kyoto Protocol's compliance system will oblige the parties to comply with its obligations; this is a role played by the enforcement branch of the Compliance Committee. In this paper, we are mainly concerned with environmental NCPs. Therefore, a full discussion of other compliance-related provisions of the Kyoto Protocol26 lies beyond our scope.

The main organ of the compliance mechanism is the newly created standing body, the Compliance Committee. It functions through a plenary, a bureau and its two internal branches, that is, the facilitative branch and the enforcement branch. ${ }^{27}$ Members of the Committee and their alternates serve in their individual capacities and must have recognized competence relating to climate change and in relevant fields such as the scientific, technical, socio-economic or legal fields. 28 Similarly, the requirements of expertise are also imposed on the Compliance Committee of the Aarhus Convention's NCP. 29

Similar to the Montreal Protocol's NCP established earlier, the Kyoto compliance procedures and mechanisms may be triggered by (a) a report prepared by an expert review team, (b) a party with respect to another party, or (c) a party that is itself not in compliance. Section VI (1) of the procedures and mechanisms provides that the Committee shall receive, through the secretariat, "questions of implementation" indicated in reports prepared by expert review teams under Article 8 of the Protocol, together with any written comments by the party which is subject to the report, or by "questions of implementation" submitted by (a) any Party with respect to itself, or (b)

24 Conference of the Parties, Marrakesh, Morocco, Oct. 29-Nov.10, 2001, Report of the Conference of the Parties on Its Seventh Session, at 64, Doc. FCCC/CP/2001/13/Add.3 (Jan. 21, 2002), available at http://unfccc.int/resource/docs/ cop7/13a03.pdf (last visited on Mar. 4, 2011), reprinted in DocumenTS IN InTERNATIONAL ENvironmental LAW 220 (Philippe Sands \& Paolo Galizzi eds., 2004). On this point, see Glenn M. Wiser et al., Non-compliance Procedures, 16 Y.B. INT' L ENVTL. L. 360, 360-1 (2007).

25 UNFCCC, Procedures and Mechanisms Relating to compliance under the Kyoto Protocol, §I, Decision-/CMP.1, available at http://unfccc.int/files/meetings/cop_11/application/pdf/cmp1_23_7_procedures_and_mechanisms_ compliance.pdf (last visited on Mar. 4, 2011).

26 E.g., arts. 5, 7, 8, 19. For an overview, see e.g., Birnie, Boyle \& Redgwell, supra note 1, at 368-70.

27 Supra note $25, \S$ II.

28 Id. $\S$ II (6).

29 On this point, see Cesare Pitea, Procedures and Mechanisms for Review of Compliance under the 2003 Protocol on Pollutant Release and Transfer Registers to the 1998 Aarhus Convention, in Treves et al., supra note 12, at 221, 225. 
any Party with respect to another Party, supported by corroborating information. Under this procedure, the secretariat has the essential task of coordinating its application. ${ }^{30}$ As Rüdiger Wolfrum and Jürgen Friedrich suggests, an innovative aspect of these new environmental procedures will be the direct link between the expert review and initiation of the compliance process. 31 This link can also be found in the Montreal NCP under which the UNEP Ozone Secretariat as a technical expert is enabled to invoke the process. ${ }^{32}$ It is hoped that, from a neutral standpoint, expert review teams - which are coordinated by the secretariat and composed of experts selected from those nominated by parties to the Convention and by intergovernmental organizations 33 - would play a role to 'de-politicize' the process.

Concerning "allocation and preliminary examination," the bureau of the Committee shall allocate questions of implementation to the appropriate branch in accordance with the mandates of each branch. The relevant branch shall undertake a preliminary examination of questions of implementation to ensure that the question (a) is supported by sufficient information, (b) is not de minimis or ill-founded, and (c) is based on the requirements of the Protocol. 34 After the preliminary examination of questions of implementation, the party concerned shall, through the secretariat, be notified of the decision. In the event of a decision to proceed, it shall be also provided with a statement identifying the question of implementation, the information on which the question is based and the branch that will consider the question. As to the 'general procedures,' it is important that competent intergovernmental and non-governmental organizations may submit relevant factual and technical information to the relevant branches. 35 Then, each branch may seek expert advice. 36

In the next section on the Kyoto Protocol's compliance system, we are mainly concerned with the recent practices of the enforcement branch. Thus, it will be useful to investigate its procedures - which are in many aspects 'judicial' in character ${ }^{37}$ - in some detail. The enforcement branch is authorized to (a) adopt a preliminary finding that the Party concerned is not in compliance with commitments under one or more of the

See Urbinati, Procedures and Mechanisms relating to Compliance under the 1997 Kyoto Protocol to the 1992 United Nations Framework Convention on Climate Change. See id. at 70.

31 Rüdiger Wolfrum \& Jürgen Friedrich, The Framework Convention on Climate Change and the Kyoto Protocol, in Beyerlin et al. (eds.), supra note 10, at 59.

32 See Yoshida, supra note 3, at 188-9.

33 The Kyoto Protocol, art. 7.

34 Supra note 25 , §VII (2).

35 Id. §VIII (4).

36 Id. §VIII (5).

37 Tim Stephens, International Courts and Environmental Protection 84-6 (2009). See also Yukari Takamura \& Yasuko Kameyama Eds., Kyoto Giteisho No KoKusai SeIDo [Kyoto Protocol's International Regime] 224 (2002). 
articles of the Protocol referred to in section V (4); or (b) determine not to proceed further with the question. 38 The enforcement branch shall, through the secretariat, notify the party concerned in writing of its preliminary finding or decision not to proceed. The decision must be available to the other Parties and to the public. ${ }^{39}$ In the case that the party concerned provides a further written submission, within four weeks from the date the enforcement branch received the further submission, it shall consider it and adopt a final decision, by indicating whether the preliminary finding is confirmed. 40 According to Rule 22 of the Rules of Procedure, a preliminary finding or a final decision is to contain, mutatis mutandis:

(a) The name of the Party concerned;

(b) A statement identifying the question of implementation addressed;

(c) The provisions of the Kyoto Protocol and decision 27/CMP.1 and other relevant decisions of the Conference of the Parties serving as the meeting of the Parties to the Kyoto Protocol that form the basis of the preliminary finding or final decision;

(d) A description of the information considered in the deliberations, including in the case of a final decision, a confirmation that the Party concerned was given an opportunity to comment in writing on all information considered;

(e) A summary of the proceedings, including an indication, in the case of a final decision of the enforcement branch, of whether its preliminary finding or any part of it as specified is confirmed;

(f) The substantive decision of the question of implementation, including the consequences applied, if any;

(g) Conclusions and reasons for the decision;

(h) The place and date of the decision; and

(i) The names of the members who participated in the consideration of the question of implementation, as well as the elaboration and adoption of the decision.

A party is allowed to 'appeal' to the Conference of the Parties serving as the meeting of the Parties to the Protocol against a final decision of the enforcement branch relating to Article 3(1) of the Protocol, if that party believes it has been denied due process. ${ }^{41}$ The Conference of the Parties can also provide general policy guidance, including on issues regarding implementation that may have implications for the work of the subsidiary bodies under the Protocol.42 
The measures to be taken by the enforcement branch are described in section XV of the procedures and mechanisms. In the case of non-compliance with Article 5 (1) or (2) (establishment of national system) or Article 7 (1) or (4) of the Protocol (updating of the annual inventory) by either Annex I or Annex II Parties, the enforcement branch may, taking into account the cause, type, degree and frequency of the non-compliance, (a) declare non-compliance and (b) develop a compliance plan submitted by the party itself for review and assessment. 43 Such a plan includes: (a) an analysis of the causes of noncompliance of the party; (b) measures that the party intends to implement in order to remedy the non-compliance; and (c) a timetable for implementing such measures within a time frame not exceeding twelve months which enables the assessment of progress in the implementation. 44 In addition, when the enforcement branch determines that an Annex I party does not meet one or more of the eligibility requirements under Articles 6, 12 and 17 of the Protocol, it shall suspend the eligibility of that party in accordance with relevant provisions under those articles. 45 On the request of the party concerned, eligibility may be reinstated in accordance with the procedure in section X (2). 46

If the enforcement branch decides that a party is in breach of its obligation to reduce emissions of greenhouse gases as set out in Article 3(1) of the Protocol, it shall: (a) deduce from the party's assigned amount for the second commitment period of a number of tones equal to 1.3 times the amount in tones of excess emissions; (b) develop a compliance action plan; and (c) suspend the party's eligibility to make transfers under Article 17 of the Protocol until the party is reinstated in accordance with section $X$ (3)(4). 47 The Kyoto Protocol provides that the procedures and mechanisms' "entailing binding consequences shall be adopted by means of an 'amendment' to this Protocol." 48 [Emphasis added] In this respect, however, at present no formal amendment seems to have been proposed. 49

Finally, the enforcement branch may, at any time, refer a question of implementation to the facilitative branch for consideration. 50

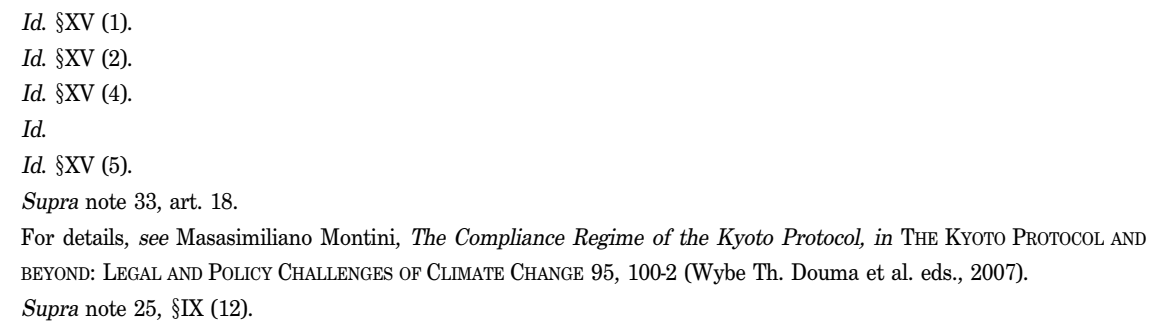




\section{Recent Practice of the Compliance Committee of the Kyoto Protocol}

The first meeting of the plenary of the Kyoto Protocol Compliance Committee was held on March 1-3, $2006 . .^{51}$ Its most recent (8th) meeting was held on September 17-18, 2010 in Bonn, Germany.52 To date, the enforcement branch has convoked eleven meetings 53 and the facilitative branch had held nine. 54 As we shall see, the enforcement branch has dealt with several important cases of non-compliance.

Among them, from the viewpoint of interpretation or application of international environmental treaties, the question of compliance by Croatia is particularly interesting. 55 Moreover, problems of implementation posed by Bulgaria and Greece seem to relate to the 'capacity-building' aspects of parties to environmental treaty regimes and of which Greece's question of implementation was previously settled in November 2008. Finally, for Canada's case relating to its national registry, the enforcement branch decided not to proceed further. These cases are examined in detail below.

\section{A. Croatia's Case: 'Politicalizing' the NCP or Maintaining Legal Standards within the Regime?}

Based on decision 13/CMP. 1, the initial report of Croatia was submitted on August 27,

51 UNFCCC, Report on the Meeting, First Meeting, Doc. CC/1/2006/4 (May 29, 2006), available at http://unfccc.int/files/kyoto_mechanisms/compliance/application/pdf/cc-1-2006-4.pdf (last visited on Mar. 4, 2011)

52 UNFCCC, Report on the Meeting, Eighth meeting, Doc. CC/8/2010/7 (Sept. 30, 2010), available at http://unfccc.int/files/kyoto_protocol/compliance/plenary/application/pdf/cc-8-2010-7_report_on_the_meeting.pdf (last visited on Mar. 4, 2011).

53 First meeting, Mar. 1-3, 2006 (Doc. CC/EB/1/2006/2, May 29, 2006); Second meeting, Sept. 5-6, 2007 (Doc. CC/EB/2/2007/3, Sept. 6, 2007); Third meeting, Mar. 4-6, 2008 (Doc. CC/EB/3/2008/2, Mar. 18, 2008); Forth meeting, Apr. 16-17, 2008 (Doc. CC/EB/4/2008/2, May 19, 2008); Fifth meeting, June 14-15, 2008 (Doc. CC/EB/5/2008/2, June 23, 2008); Sixth meeting, Oct. 6-7, 2008 (Doc. CC/EB/6/2008/3, Oct. 30, 2008); Seventh meeting, Oct. 11-13, 2009 (Doc. CC/EB/7/2009/2, Oct. 26, 2009); Eighth meeting, Nov. 23-24, 2009 (Doc. CC/EB/8/2009/2, Dec. 4, 2009); Ninth meeting, May 10-12, 2010 (Doc. CC/EB/9/2010/2, May 25, 2005); Tenth meeting, June 28, 2010 Doc. CC/EB/10/2010/2, July 6, 2010); Eleventh meeting, Sept. 16, 2010 (Doc. CC/EB/11/2010/2, Sept. 30, 2010).

54 First meeting, Mar. 1-3, 2006 (Doc. CC/FB/1/2006/2, May 30, 2006); Second meeting, May 30-31, 2006 (Doc. CC/FB/2/2006/2, Sept. 6, 2006); Third meeting, June 20-22, 2006 (Doc. CC/FB/3/2006/2, Sept. 6, 2006); Forth meeting, Sept. 6, 2006 (Doc. CC/FB/4/2006/2, Sept. 15, 2006); Fifth meeting, Sept. 6, 2007 (Doc. CC/FB/5/2007/2, Sept. 6, 2007); Sixth meeting, Oct. 7, 2008 (Doc. CC/FB/6/2008/2, Oct. 30, 2008); Seventh meeting, Oct. 12, 2009 (Doc. CC/FB/7/2009/2, Oct. 26, 2009); Eighth meeting, July 1, 2010 (Doc. CC/FB/8/2010/4, July 7, 2010); Ninth meeting, Sept. 16, 2010 (Doc. CC/FB/9/2010/2, Sept. 30, 2010).

55 Infra note 62 . 
2008. Namely, decision 13/CMP.1 requested that each party include in Annex I with a commitment inscribed in Annex B to submit the initial report to the secretariat, prior to January 1, 2007, or one year after the entry into force of the Kyoto Protocol for that party, whichever occurred later.56 In response, on August 26, 2009, an international team of experts (the expert review team) delivered its in-depth initial review report of Croatia. 57 The report concluded that the addition of 3.5 million tones $(\mathrm{Mt})$ carbon dioxide equivalent (eq) to the base year level for the calculation of Croatia's assigned amount was not in compliance with Article 3(7)(8) of the Kyoto Protocol and the modalities for the accounting of assigned amounts under Article 7(4) of the Protocol (decision 13/CMP.1):58 assigned amount of a party sets its base emission limit for five years, that is, the first commitment period of the Protocol (2008 to 2012). In addition, the expert review team observed that the revised calculation of Croatia's commitment-period reserve, based on the revised calculation of its assigned amount following decision 7/CP.12,59 was not in accordance with paragraph 6 of the annex to decision 11/CMP.1. As the secretariat notes, the question is whether a decision taken under the UNFCCC would allow Croatia to issue more credits under the Kyoto Protocol, which at the same time would increase the commitment-period reserve.60

On August 28, 2009, the bureau of the Compliance Committee allocated the questions of implementation to the enforcement branch and it decided to proceed, by noting that the questions were supported by sufficient information. 61 Thereinafter, on October 9, 2009, Croatia made a written submission 62 and requested a hearing. 63 At the hearing, as stated in its written submission, Croatia argued that the country was entitled to add 3.5 million tones carbon dioxide equivalent to its 1990 level of greenhouse gas emissions not controlled by the Montreal Protocol. Its purpose was to establish the level of emissions for the base year for implementing its commitments under Article 3 of the Kyoto Protocol. This logic was based on decision 7/CP.12, which stipulates that:

\footnotetext{
56 See Decision 13/CMP. 1, in UNFCCC, Report of the Conference of the Parties serving as the Meeting of the Parties to the Kyoto Protocol on its First Session, at 23, Doc. FCCC/KP/CMP/2005/8/Add.2 (Mar. 30, 2006), available at http://unfcc.int/resource/docs/2005/cmp1/eng/08a02.pdf (last visited on Mar. 4, 2011).

57 See UNFCCC, Report of the review of the initial report of Croatia, Doc. FCCC/IRR/2008/HRV (Aug. 26, 2009), available at http://unfccc.int/resource/docs/2009/irr/hrv.pdf (last visited on Mar. 4, 2011).

58 Id. para. 157 , at 37.

59 See Decision 7/CP.12, Level of emissions for the base year of Croatia, in Doc. FCCC/CP/2006/5/Add.1, at 15.

60 Informal information note by the secretariat, updated on Oct. 29, 2010, available at http://unfccc.int/files/kyoto_ protocol/compliance/questions_of_implementation/application/pdf/hrv_update_to_informal_information_note_re_pla n_20101029.pdf (last visited on Mar. 4, 2011).

61 UNFCCC, The questions of Implementation, para. 8, at 2, Doc.CC-2009-1-2/Croatia/EB (Sept. 8, 2009).

62 Written Submission from Croatia, CC-2009-1-5-Croatia/EB (Oct. 9, 2009).

63 Request for Hearing from Croatia, CC-2009-1-4-Croatia/EB (Sept. 25, 2009).
} 
"Croatia, having invoked Article 4, paragraph 6, of the Convention, shall be allowed to add $3.5 \mathrm{Mt} \mathrm{CO} 2$ equivalent to its 1990 level of greenhouse gas emissions not controlled by the Montreal Protocol for the purpose of establishing the level of emissions for the base year for implementation of its commitments under Article 4, paragraph 2, of the Convention." [Italic added] According to Croatia, its specific circumstances had been recognized within the framework of the UNFCCC during negotiations on the base year.64 For determining all the circumstances surrounding Croatia's implementation of its emission reduction commitments, furthermore, both the principle of their common but differentiated responsibilities and the principle of that economic development should be taken into account. 65

On October 13, 2009, the seventh meeting of the enforcement branch adopted a preliminary finding of Croatia's non-compliance. 66 The branch suggested that the degree of flexibility available to the parties included in Annex I undergoing the process of transition to a market economy be fundamentally and essentially different between the two legal instruments or regimes (i.e., the Kyoto Protocol and the UNFCCC). It includes flexibility for the implementation of commitments under Article 3 of the Protocol, which states that flexibility for these Parties is limited only to the use of an historical base year or period other than 1990. Hence, the enforcement branch determined that decision 7/CP.12 under the UNFCCC did not provide a basis under the Protocol for Croatia to add 3.5 $\mathrm{Mt} \mathrm{CO}_{2}$ eq. to its level of emissions without an additional decision by the CMP on Croatia's special circumstances. Thus, the enforcement branch applied the following consequences: (a) Croatia was declared to be in non-compliance; (b) Croatia must develop a plan referred to in section XV (1) of the procedures and mechanisms relating to compliance under the Protocol and submit it to the enforcement branch within three months; and (c) Croatia was not eligible to participate in the mechanisms under Articles 6 (trading of emission reduction units), 12 (CDM) and 17 (emission trading) of the Protocol.67 If these consequences are applied, in fact, Croatia may neither sell or transfer credits, nor claim any credits, until the enforcement branch decides on the matter of Croatia's return to compliance.

The preliminary finding of Croatia's non-compliance was confirmed by the

Id.

66 Preliminary Finding, CC-2009-1-6-Croatia/EB (Oct. 13, 2009).

67 On the Kyoto flexible mechanisms, see e.g., David Freestone \& CharlotTe Streck Eds., LeGal Aspects of Implementing the Kyoto Protocol Mechanisms: Making Kyoto WorK (2005); Michael Rodi et al., Implementing the Kyoto Protocol in a Multidimensional Legal System: Lessons from a Comparative Assessment, 16 Y.B. INT'L ENVTL. L. 3 , at 10-20 (2007). 
enforcement branch on November 26, 2009.68 It is interesting that the enforcement branch adopted a resolute stance supporting Article 31 of the Vienna Convention on the Law of Treaties and relevant customary international law, by saying that: "In addressing the questions of implementation before it, the enforcement branch followed this general rule and was not persuaded that it is necessary to follow another method of interpretation." [Italic added] Contrary to Croatia's arguments, the enforcement branch suggested that the legal application of decision 7/CP.12 to the subsequent treaty regime of the Kyoto Protocol did not follow from any of the provisions of the Protocol or CMP decisions which Croatia referred to. In other words, "Since the COP and the CMP are two distinct decision-making bodies, the fact that all Parties to the Kyoto Protocol are also Parties to the United Nations Framework Convention on Climate Change does not provide a sufficient basis for establishing the application of COP decisions under the Kyoto Protocol." 69

On January 4, 2010, Croatia submitted comments against the final decision of the enforcement branch. 70 Croatia stated that the enforcement branch was obliged to interpret the Kyoto Protocol "as an extension of the Convention and in light of its objectives and purpose, as opposed to treating it as an entirely separate treaty" [Italic added] and that the final decision was not in line with Article 31(3)(b) of the Vienna Convention on the Law of Treaties concerned with "any subsequent practice in the application of the treaty which establishes the agreement of the parties regarding its interpretation." 71 [Italic added] As Richard K. Gardner rightly points out, the prominent role of the practice of parties to a treaty is one of the characteristics of the Vienna Convention on the Law of Treaties, which sheds light on a difference of approach observed in the process of the interpretation of international law rules, 72 and recourse to it as a means of interpretation is generally well-established in the jurisprudence of international courts. ${ }^{73}$ Nevertheless, it must be emphasized that, as Ian Sinclair pointed out, a practice is a sequence of facts or acts and cannot be generally established by one isolated fact or act or even by several

UNFCCC, Final Decision, para. 6, at 2, Doc.CC-2009-1-8/Croatia/EB (Nov. 26, 2009), available at http://unfccc.int/files/kyoto_protocol/compliance/enforcement_branch/application/pdf/cc-2009-1-8_croatia_ eb_final_decision.pdf (last visited on Mar. 4, 2011).

69 Id. at 2.

70 UNFCCC, Commemts from Croatia on the Fianl Decision, para. 6, at 2 Doc.CC-2009-1-9/Croatia/EB, (Jan. 4, 2010), available at http://unfccc.int/files/kyoto_protocol/compliance/enforcement_branch/application/pdf/cc-2009-19_croatia_eb_comments_from_croatia_on_the_final_decision-website.pdf. (last visited on Mar. 4, 2011).

71 Id. at 2-3 (underline original).

72 Richard K. GaRdner, Treaty Interpretation 225 (2008).

73 Ralf Günter Wetzel \& Dietrich Rauschning, The Vienna Convention on the LaW of Treaties: TravauX Preparatoires 253-4 (1978). See also Alexander Orakhelashvili, The Interpretation of Acts and Rules in Public INTERNATIONAL LAW 355-9 (2008). 
individual applications 74 and thus the world of Is or Sein should not be easily incorporated in the normative system (Sollen) of binding international treaty regimes. Further, in Croatia's view, the enforcement branch's decision is "absurd and unreasonable" and therefore, in accordance with Article 32 of the Vienna Convention on the Law of Treaties, "supplementary means of interpretation including the preparatory work of the treaty and [the circumstances of its conclusion] should be taken into account." 75 However, it may be difficult to argue that the interpretation of the enforcement branch is 'absurd' or 'unreasonable,' since its method of interpretation is itself based on an ordinary reading of the Vienna Convention rules. Unlike other compliance mechanisms of environmental treaties, in the case of the enforcement branch of the Compliance Committee, when elected by the COP/MOP, members are specifically required to have legal experience. ${ }^{76}$ 'Political interpretation' of the Kyoto Protocol by way of a reference to a decision under the Convention (i.e., decision 7/CP.12) would be likely to cause legal uncertainty of the entire evolving international climate change regime.

Although the plan required by the enforcement branch was due on March 2, 2010, on March 8, 2010, Croatia indicated that it did not intend to submit such a plan in view of its submission of an appeal against the final decision.77 Therefore, at the time of writing, Croatia remains subject to the final decision of the breach mentioned above.78

\section{B. Bulgaria's Case: A Matter of Capacity-Building}

On April 13, 2009, Bulgaria submitted its 2009 annual inventory submission.79 It was intended to provide information to maintain its eligibility to participate in the market mechanisms including emissions trading (Article 17), clean development mechanism (Article 12) and joint implementation (Article 6). Subsequently, the report of the annual submission, coordinated by the UNFCCC secretariat was published on March 9, 2010. In the report, the expert review team observed that the Bulgarian national system did not work fully and consistently with the general and specific functions required of

74 Ian Sinclair, The Vienna Convention on the Law of Treaties 137 (2d ed. 1984).

75 See Doc.CC-2009-1-9/Croatia/EB, para. 4, at 3 (Jan. 4, 2010).

76 Supra note $25, \S \mathrm{V}(3)$.

77 Supra note 60, at 2.

78 UNFCCC, Report on the Meeting, Eleventh Meeting, para.7, at 2, Doc. CC/EB/11/2010/2 (Sept. 30, 2010), available at http://unfccc.int/files/kyoto_protocol/compliance/enforcement_branch/application/pdf/cc-eb-11-20102_report_on_the_meeting.pdf (last visited on Mar. 4, 2011).

79 UNFCC, Report of the Individual Review of the Annual Submission of Bulgaria Submitted in 2009, Doc.FCCC/ARR/2009/BGR (Mar. 9, 2010), available at http://unfccc.int/resource/docs/2010/arr/bgr.pdf (last visited on Mar. 4, 2011). 
national systems as set out in the "Guidelines for national systems for the estimation of emissions by sources and removals by sinks under Article 5 (1) of the Kyoto Protocol" (decision 19/CMP.1). 80 Further, it found that Bulgaria's arrangements for institutional as well as arrangements measuring technical competence of the staff within the national system for the inventory development process were insufficient for preparing the annual submission. 81

On March 9, 2010, an official notification of the question of implementation was sent to Bulgaria. A week later, the question was formally allocated to the enforcement branch. On March 31, after conducting the preliminary examination in accordance with section VII (2) and section X (1)(a) of the procedures and mechanisms relating to compliance under the Protocol, the enforcement branch decided on consensus to proceed with the implementation review. 82 After a month, on May 5, 2010, the enforcement branch received a written submission 83 from Bulgaria requesting a hearing. 84 During the hearing, Bulgaria reportedly admitted that it had encountered problems with its institutional arrangements and the technical competence of its staff, due to a lack of financial and human resources.85 Since then, on May 12, 2010, "after the elaboration of a decision" held in private, the enforcement branch adopted a preliminary finding on Bulgaria's non-compliance. 86 Finally, the enforcement branch decided to apply the following consequences: (a) Bulgaria was declared to be in noncompliance; (b) Bulgaria must develop and submit a plan referred to in section XV (1) of the procedures and mechanisms within three months to the enforcement branch; and (c) Bulgaria's eligibility to participate in the mechanisms under Articles 6, 12 and 17 of the Kyoto Protocol was suspended, pending the settlement of the question of implementation. 87 The preliminary finding on Bulgaria's non-compliance was

81 Id

82 UNFCCC, Decision on Preliminary Examination, para. 6, at 2, Doc. CC-2010-1-2/Bulgaria/EB (Mar. 31, 2010), available at $\mathrm{http} / / / \mathrm{unfcc}$.int/files/kyoto_protocol/compliance/questions_of_implementation/application/pdf/cc-20101-2_bulgaria_eb_decision_on_preliminary_examination.pdf (last visited on Mar. 4, 2011).

83 UNFCCC, Written Submission from Bulgaria, Doc. CC-2010-1-5/Bulgaria/EB (May 6, 2010), available at http://unfccc.int/files/kyoto_protocol/compliance/questions_of_implementation/application/pdf/cc-2010-15_bulgaria_eb_written_submission_from_bulgaria_main_body.pdf (last visited on Mar. 4, 2011).

84 UNFCCC, Preliminary Finding, Doc. CC-2010-1-6/Bulgaria/EB, para. 10, at 2 (May 12, 2010), available at http://unfccc.int/files/kyoto_protocol/compliance/questions_of_implementation/application/pdf/cc-2010-16_bulgaria_eb_preliminary_finding.pdf (last visited on Mar. 4, 2011); UNFCC, Report on the Meeting, paras. 10-11, at 3, CC/EB/9/2010/2 (May 25, 2010), available at http://unfccc.int/files/kyoto_mechanisms/compliance/ enforcement_branch/application/pdf/cc-eb-9-2010-2_report_on_the_meeting.pdf (last visited on Mar. 4, 2011). Supra note 84, para. 15, at 3 (May 12, 2010).

6 Id.

87 Id. para. 20, at 4 . 
confirmed on June 28, 2010.88

On August 12, 2010, Bulgaria submitted a revised plan titled, "Updated Improvement Plan for ensuring the effective and timely functioning of Bulgarian National Inventory System in accordance with the requirements of Article 5.1 of the Kyoto Protocol and Decision 19/CMP.1, as well as the relevant requirements of EU." 89 However, the enforcement branch decided that this plan did not fully meet the requirements in the procedures and mechanisms relating to compliance, the rules of procedure of the Compliance Committee and the preliminary finding. ${ }^{90}$ The branch also noted that "it does not include an analysis of the causes of the non-compliance as required by section XV, paragraph 2 (a)." 91 Bulgaria was thus required to submit a complete plan by October 1, 2010. The country submitted a document titled, "Compliance action plan submitted in accordance with paragraph 20 (b) of the preliminary finding (CC-2010-1-6/Bulgaria/EB), confirmed by the final decision of the Enforcement Branch concerning Bulgaria (CC-2010-1-8/Bulgaria/EB) and in accordance with section XV, paragraphs $1 \& 2$ and rule 25 bis of the Rules of Procedures of the Compliance Committee." 92 Even then, the enforcement branch decided to defer the continuation of the review and assessment of the revised plan until after the publication of the expert review team's report of the review of the 2010 annual submission of Bulgaria. 93

\section{Greece's Case: The Position and Use of Its National System}

The initial report of Greece was submitted on December 29, 2006.94 Analyzing the initial

88 UNFCCC, Final Decision, Doc. CC-2010-1-8/Bulgaria/EB (June 28, 2010).

89 UNFCCC, Updated Improvement Plan, Doc. CC-2010-1-11/Bulgaria/EB (Aug. 12, 2010), available at http://unfccc.int/files/kyoto_protocol/compliance/questions_of_implementation/application/pdf/cc-2010-111_bulgaria_eb_plan_pursuant_to_final_decision.pdf (last visited on Mar. 4, 2011).

90 UNFCCC, Conference of the Parties Serving as the Meeting of the Parties to the Kyoto Protocol, para. 39, at 9, Doc. FCCC/KP/CMP/2010/6 (Oct. 8, 2010), available at http://unfccc.int/resource/docs/2010/cmp6/eng/06.pdf (last visited on Mar. 4, 2011).

91 UNFCCC, Report on the Meeting, 11 th Meeting, Doc. CC/EB/11/2010/2, para. 14, at 3 (Sept. 30, 2010).

92 UNFCCC, Compliance Action Plan, Doc. CC-2010-1-12/Bulgaria/EB (Oct. 4, 2010), available at http://unfcc.int/files/ kyoto_protocol/compliance/questions_of_implementation/application/pdf/cc-2010-1-12_bulgaria_eb_updated_ compliance_action_plan.pdf (last visited on Mar. 4, 2011).

93 UNFCCC, Consideration of the Question of Implementation with Respect to Bulgaria Provisional Agenda and Annotations, para. 4, at 2, Doc. CC/EB/12/2010/1 (Dec. 21, 2010), available at http://unfccc.int/files/kyoto_protocol /compliance/enforcement_branch/application/pdf/cc-eb-12-2010-1_provisional_agenda_and_annotations_21122010.pdf (last visited on Mar. 4, 2011); UNFCC, Decision to Defer the Completion of the Review and Assessment of the Plan Submitted under Paragraph 2 of Section XV, CC-2010-1-13/Bulgaria/EB (Oct. 25, 2010), available at http://unfccc.int/files/kyoto_protocol/compliance/ questions_of_implementation/application/pdf/cc-2010-1-13_bgreb_decision_on_deferment_of_r_and_a_of_plan.pdf (last visited on Mar. 4, 2011).

94 UNFCCC, Report of the Review of the Initial Report of Greece, para. 3, at 3, Doc. CC-2007-1-1/Greece/EB (Jan. 8, 2008), available at http://unfccc.int/files/kyoto_protocol/compliance/enforcement_branch/application/pdf/cc-2007-1- 
report submitted by Greece and the additional information obtained, the expert review team concluded that the national system of Greece did not fully comply with the guidelines for both national systems under Article 5 (1) of the Kyoto Protocol (decision 19/CMP.1), and the guidelines for the preparation of the information required under Article 7 of the Kyoto Protocol (decision 15/CMP.1). 95 In particular, the expert review concluded that the maintenance of institutional and procedural arrangements, arrangements for the technical competence of the staff, and the capacity for timely performance of a national system were unsettled problems. 96 The question of implementation was related to the eligibility requirement referred to in paragraph 31(c), annex to decision 3/CMP.1, and so forth. On April 14, 2008, Greece was given an official notification of this question of compliance. Subsequently, Greece made a written submission titled, "Greek National GHG Inventory System" (Athens, February 2008). ${ }^{97}$ In addition, at the request of Greece, a hearing was held on March 4-5, 2008.98

Based on written and oral information presented by Greece, the enforcement branch concluded that the unresolved problems resulted in non-compliance with the abovementioned guidelines when the initial report of Greece was reviewed. Thus, the enforcement branch decided to apply the following three consequences: (a) Greece was declared to be in non-compliance; (b) Greece was to develop a plan referred to in section XV (1) of the procedures and mechanisms relating to compliance under the Protocol and submit it within three months to the enforcement branch. Such plan should demonstrate measures to assure the maintenance of the national system through transitions and include administrative arrangements to support an in-country review by the expert team of the new national system of Greece; and (c) Greece was not eligible to participate in the mechanisms under Articles 6, 12 and 17 of the Protocol pending the resolution of the question of implementation. ${ }^{99}$ These consequences were confirmed as a final decision by the enforcement branch of the Compliance Committee.100 Although Greece submitted a plan pursuant to the final decision,101 at its sixth meeting, the enforcement branch decided to request Greece to submit a revised plan as early as possible.102

After then, on October 27, 2008, Greece submitted a revised and detailed paper, titled

1_greece_eb_report_of_the_review_of_ir_of_greece.pdf (last visited on Mar. 4, 2011).

95 UNFCCC, Report of the Review of the Initial Report of Greece, para. 244, at 57, Doc. FCCC/IRR/2007/GRC (Dec. 28, 2007), available at http://unfccc.int/resource/docs/2007/irr/grc.pdf (last visited on Mar. 4, 2011).

96 Id.

97 UNFCCC, Written Submission of Greece, Doc. CC-2007-1-5/Greece/EB (Feb. 26, 2008). See also UNFCCC, Preliminary Finding, para. 8, at 2, Doc. CC-2007-1-6/Greece/EB (Mar. 6, 2008).

98 Id. paras. 8-9, at 2.

99 Id. para. 18, at 4.

100 UNFCCC, Final Decision, para. 5, at 2, Doc. CC-2007-1-8/Greece/EB (Apr. 17, 2008).

101 UNFCCC, Plan Pursuant to Final Decision, Doc. CC-2007-1-9/Greece/EB (July 17, 2008).

102 UNFCCC, Decision on Review and Assessment of Plan, Doc. CC-2007-1-10/Greece/EB, paras. 3-4, at 1 (Oct. 7, 2008). 
"Revised Plan under paragraph 4 of the Decision CC-2007-1-10/Greece/EB/7-10-8 on the Review and Assessment of the Plan submitted by Greece" (Athens, October 2008).103 Regarding the document, the enforcement branch determined that a question of noncompliance would not be continued anymore, and that Greece was then fully eligible to participate in the Kyoto Protocol's mechanisms. 104

\section{Canada's Case: To Proceed or Not to Proceed?}

Canadian case is controversial because the enforcement branch ultimately decided not to proceed with its question of compliance. As required by decision 13/CMP.1, Canada submitted its initial report to the secretariat on March 15, 2007.105 On April 11, 2008, the review of the initial report of Canada was made public almost one year after its submission. 106 Then, Canada suggested that the status of its 'national registry' be not in accordance with the provisions of the modalities for accounting of the assigned amounts under Article 7 (4) of the Kyoto Protocol. Further, the expert review team pointed out that "Canada has not provided information, as required by the guidelines for the preparation of the information required under Article 7 of the Kyoto Protocol (decision 15/CMP.1), to the ERT on how its national registry performs the functions defined in the annex to decisions 13/CMP.1 and 5/CMP.1, and how the registry complies with the requirements of the technical standards for data exchange between registry systems." 107

After conducting the preliminary examination, the enforcement branch decided to proceed and communicated its view that the question of implementation was supported by sufficient evidence.108 In response, on June 6, 2008, Canada submitted a paper titled, "Question of Implementation: Canada's National Registry System under the Kyoto Protocol" (Ottawa, 5 June 2008).109 Canada argued that, since its initial

103 UNFCCC, Revised Plan Pursuant to Final Decision, Doc. CC-2007-1-11/Greece/EB (Oct. 27, 2008).

104 UNFCCC, Annual Report of the Compliance Committee to the Conference of the Parties Serving as the Meeting of the Parties to the Kyoto Protocol, para. 26, at 6, Doc. FCCC/KP/CMP/2009/17 (Nov. 2, 2009), available at http://unfccc.int/files/kyoto_protocol/compliance/plenary/application/pdf/cc-6-2009-3_annual_report_of_the_ compliance_committee_to_the_cmp.pdf (last visited on Mar. 4, 2011).

105 UNFCCC, Report of the Review of the Initial Report of Canada, para. 3, at 3, Doc. FCCC/IRR/2007/CAN (Apr. 17, 2008), available at http://unfccc.int/files/kyoto_protocol/compliance/enforcement_branch/application/pdf/cc-2008-11_canada_eb_report_of_the_review_of_ir_of_canada.pdf (last visited on Mar. 4, 2011).

106 In this respect, the plenary of the Compliance Committee expressed concern. See UNFCCC, Conference of the Parties Serving as the Meeting of the Parties to the Kyoto Protocol, para. 19, at 8, Doc. FCCC/KP/CMP/2008/5 (Oct. 31, 2008), available at http://unfccc.int/files/kyoto_protocol/compliance/plenary/application/pdf/kpcmp5_ advance.pdf (last visited on Mar. 4, 2011).

107 Doc. FCCC/IRR/2007/CAN, supra note 105, para. 139, at 31.

108 UNFCCC, Decision on Preliminary Examination, para. 6, at 1, Doc. CC-2008-1-2/Canada/EB (May 2, 2008).

109 UNFCCC, Written Submission to the Enforcement Branch of the Compliance Committee, Doc. CC-2008-1-5/ Canada/EB (June 6, 2008). 
report, 110 it had worked steadily toward the establishment of a national registry to ensure the accurate accounting of the issuance, holding, transfer, acquisition, cancellation and retirement of emission reduction units ("ERUs"), certified emission reductions ("CERs"), assigned amount units ("AAUs"), etc.111 In sum, Canada noted that it had "established a national registry that meets the functional requirements of Article 7 of the Kyoto Protocol and the Data Exchange Standards." 112 Thus, Canada asked the enforcement branch not to proceed further on this matter.113

As requested by Canada, a hearing was held on June 14, 2008.114 There, Canada reported on the establishment and testing of its national registry, by providing expert testimony on how its national registry meets the relevant requirements under the Kyoto Protocol.115 In light of the information submitted, the enforcement branch decided that: (a) the status of Canada's national registry resulted in non-compliance with the guidelines and the modalities on the publication date of the review report; and (b) there is a sufficient factual basis to avert a finding of non-compliance on the date of this decision.116[Italic added] Therefore, the enforcement branch determined not to proceed further with Canada's compliance question. However, in response to this decision, Canada submitted "Further Written Submission of Canada under Section X, paragraph 1(e) of the Annex to Decision 27/CMP.1" (Ottawa, July 11, 2008), saying that the enforcement branch should delete paragraph 17(a) from its "Decision Not To Proceed Further," 117 since in Canada's view, this conclusion fell outside the mandate of the branch in decision 27/CMP.1.118 Namely, Canada argued that in accordance with sections V (4) and XV (1), the enforcement branch was required only to apply consequences to present, not past, situations where non-compliance was at issue.119[Italic added]

110 Report contained in Doc. CC-2008-1-1/Canada/EB (Apr. 17, 2008).

111 Doc. CC-2008-1-5/Canada/EB, supra note 109, para. 10, at 5 (June 6, 2008).

112 Id. para. 9, at 5.

113 Id. para. 18, at 13.

114 UNFCCC, Decision Not to Proceed Further, para. 9, at 2, Doc. CC-2008-1-6/Canada/EB (June 15, 2008).

115 UNFCCC, Report on the Meeting, Fifth Meeting, para. 12, at 3, Doc. CC/EB/5/2008/2 (June 23, 2008).

116 Doc. CC-2008-1-6/Canada/EB, supra note 114, para. 916, at 3.

117 UNFCCC, Decision on Preliminary Examination, Doc. CC-2008-1-2/Canada/EB (May 2, 2008).

118 UNFCCC, Further Written Submission of Canada, paras. 6-11, at 5-6, Doc. CC-2008-1-7/Canada/EB (July 14, 2008). See also UNFCCC, Conference of the Parties Serving as the Meeting of the Parties to the Kyoto Protocol, $4^{\text {th }}$ Sess., at 46, FCCC/KP/CMP/2008/5 (Oct. 31, 2008), available at http://unfccc.int/files/kyoto_protocol/compliance/ plenary/application/pdf/kpcmp5_advance.pdf (last visited on Mar. 4, 2011).

119 The Annex to decision 27/CMP.1 Section V (4) reads: "The enforcement branch shall be responsible for determining whether a Party included in Annex I is not in compliance with: (a) Its quantified emission limitation or reduction commitment under Article 3, paragraph 1, of the Protocol; (b) The methodological and reporting requirements under Article 5, paragraphs 1 and 2, and Article 7, paragraphs 1 and 4, of the Protocol; and (c) The eligibility requirements under Articles 6, 12 and 17 of the Protocol." 


\section{E. South Africa's Case: Practice of the Facilitative Branch}

With regard to the facilitative branch, on May 26, 2006, a submission was made by South Africa as Chairman of the Group 77 and China concerning non-compliance with Article 3 (1) of the Kyoto Protocol by fifteen parties. The following countries were: Austria, Bulgaria, Canada, France, Germany, Ireland, Italy, Latvia, Liechtenstein, Luxembourg, and Poland.120 The facilitative branch conducted a preliminary examination of this case from May 31, 2006 to June 20, 2006. On June 21, 2006, after failing to reach agreement by consensus, the facilitative branch decided to resort to vote. Concerning two of the named parties, Latvia and Slovenia, the branch adopted a decision not to proceed by a majority of three-fourths of the members present and voting. The branch's decision reflected that both countries submitted their fourth national communications and their progress reports on May 25 and June 12, respectively. 121

However, the facilitative branch failed to adopt a decision 'to proceed or not to proceed' regarding the other thirteen countries. It was argued, for instance, that the South African submission was neither supported by information concerning the question of implementation, nor did it substantiate that the question relates to any of the specific commitments under the Kyoto Protocol specified in section VII (5)(6).122 At the same time, however, four members allegedly supported proceeding with the case, owing to the parties' failure to submit a national communication.123

Consequently, the branch could not complete the preliminary examination within three weeks from the date of the submission from South Africa, in accordance with section VII (3) of the procedures and mechanisms relating to compliance under the Protocol.124 This may suggest a need for a partial review of the decision-making process

120 UNFCCC, Submission by South Africa, as Chairman of the Group of 77 and China, on Behalf of the Group of 77 and China: Doc. CC-2006-1-1/FB; Doc. CC-2006-2-1/FB; Doc. CC-2006-3-1/FB; Doc. CC-2006-4-1/FB; Doc. CC-2006-51/FB; Doc. CC-2006-6-1/FB; Doc. CC-2006-7-1/FB; Doc. CC-2006-8-1/FB; Doc. CC-2006-9-1/FB; Doc. CC-2006-10-1/FB; Doc. CC-2006-11-1/FB; Doc. CC-2006-12-1/FB; Doc. CC-2006-13-1/FB; Doc. CC-2006-14-1/FB; Doc. CC-2006-15-1/FB, available at http://unfccc.int/playground/items/5516.php (last visited on Mar. 4, 2011). See also Urbinati, supra note 30 , at 83 .

121 UNFCCC, Annual Report of the Compliance Committee to the Conference of the Parties Serving as the Meeting of the Parties to the Kyoto Protocol, para. 22, at 6, Doc. FCCC/KP/CMP/2006/6 (Sept. 22, 2006), available at http://maindb.unfccc.int/library/view_pdf.pl?url=http://unfccc.int/resource/docs/2006/cmp2/eng/06.pdf (last visited on Mar. 4, 2011).

122 UNFCCC, Facilitative Branch, Report on the Meeting, para. 4(c), at 4, Doc. CC/FB/3/2006/2 (Sept. 6, 2006), available at http://unfccc.int/files/kyoto_mechanisms/compliance/application/pdf/cc-fb-3-2006-2.pdf (last visited on Mar. 4, 2011).

123 Glenn M. Wiser et al., Non-compliance Procedure, 17 Y.B. InT' L ENvTL. L. 278, at 279 (2008).

124 See Doc. CC/FB/3/2006/2, supra note 122, para. 5, at 5. 
within the facilitative branch. 125

\section{Conclusion}

Following the analysis of the early operation of the Kyoto Protocol's NCP, it may be reasonable to say that the climate change regime has instituted a general procedural framework for dealing 'effectively' with non-compliance with the environmental treaty obligations. As we have seen, based on the procedures and mechanisms, the enforcement branch of the Compliance Committee, international expert review teams, the secretariat and the parties concerned closely cooperate with each other in order to settle emerging non-compliance cases - It may also be suggested that this is a kind of cooperation in international environmental law ${ }^{126}$ at the procedural level of supervision and also designates gradual developments of so-called "international administrative law." 127 Within the framework of the compliance procedure, almost all national bodies concerned properly function as international law organs for the protection of global environment.

The observations of the expert review teams have generally been accepted by the enforcement branch as reliable sources of opinions. After "taking into account the cause, type, degree and frequency of the non-compliance" of the parties in question, the enforcement branch has decidedly declared non-compliance without hesitation. Noticeable is that the Kyoto Protocol's NCP has prepared a multilateral forum which enables both the parties and the enforcement branch to base their arguments on international legal perspectives. As was shown in the case of Croatia, it is significant to see that the non-complying party and the branch are eager to rely on the interpretative rules provided for in the Vienna Convention of the Law of the Treaties. Furthermore, though Croatia invoked the "principle of common-but-differentiated responsibilities" which the facilitative branch is explicitly allowed to apply128 - and other political

\footnotetext{
125 Tomohito Usuki, Kyōto Giteisho no Junshu Tetsuzuki [Compliance Procedures under the Kyoto Protocol: Facilitative and Enforcement Approaches to Non-Compliance] 59 Dōshisha Höaku [Dōshisha L. Rev.] 115-6 (2007).

126 On this notion, see Peter-Tobias Stoll, The International Environmental Law of Cooperation, in ENFoRciNG Environmental Etandards: Economic Mechanisms as Viable Means? 30 (Rüdiger Wolfrum ed., 1996).

127 For a discussion of "international administrative law," see Nico Krisch \& Benedict Kingsbury, Introduction: Global Governance and Global Administrative Law in the International Legal Order, 17 EUR. J. INT'L L. 1 (2006). On its earlier development, see e.g., J. L. Kunz, Die StaAtenverbindungen 373-404 (1929); The Changing LaW of Nations: ESSAYS ON INTERNATIONAL LAW ch. 25 (1968).

128 Supra note 25, §IV (4).
} 
considerations in its submissions and at its hearing, the enforcement branch regarded such logic and reasoning as legally insupportable. This might be considered as a good example of partial 'legalization' of environmental NCPs in practice, which often tends to assume a political character. 129

Finally, it should be briefly added that the International Law Association ("ILA")'s Committee on the Legal Principles relating to Climate Change was established in November 2008 at the initiative of its Japan branch. 130 The first report of the ILA Climate Change Committee was written based on a paper prepared by the Japan branch committee on climate change. 131 The new Committee will deal with legal issues and principles or rules relating to global climate change including compliance procedures and mechanisms of the international climate change treaty regime. It is strongly hoped that academic research efforts would also contribute to improving the compliance system of the environmental regime, which would be faced with expected noncompliance of the 2012 emissions targets.

129 In this respect, see Geir Ulfstein ed., Making Treaties Work: Human Rights, Environment and Arms Control 132 (2007). See also Akio Morita, KoKusai Kontoróru No Riron to JukKō [International Supervision in Theory and Practice] 150 (2000) (noting that compliance procedures consisted of governmental representatives might be politicized).

130 See Report of National Committee - Legal Principles relating to Climate Change: Preliminary Issues on the Methodology and Scope of the Work, 52 JAP. Y.B. INT' L L. 500 (2009).

131 The Legal Principles relating to Climate Change, available at http://www.ila-hq.org/en/committees/index.cfm/cid/1029 (last visit on Mar. 4, 2011). Japan's paper is reprinted in 52 JAPAN Y.B. INT'L L. 500 (2009). As to the officers and members of the committee, see Kazuhiro Nakatani, Activity of the Japan Branch Committee on Climate Change, 52 JAPAN Y.B. INT'L L. 911-2 (2009). 
